\title{
Prevalence and Correlates of Physical Fighting Among School Going Students Aged 13 - 15 in the Association of Southeast Asian Nations
} (ASEAN) Member States

\author{
Karl Peltzer, ${ }^{1,2,}{ }^{*}$ and Supa Pengpid ${ }^{2,3}$ \\ ${ }^{1}$ HIV/AIDS/STIs and TB (HAST), Human Sciences Research Council, Pretoria, South Africa \\ ${ }^{2}$ Department of Research Innovation and Development, University of Limpopo, Turfloop Campus, Sovenga, South Africa \\ ${ }^{3}$ ASEAN Institute for Health Development, Mahidol University, Salaya, Phutthamonthon, Nakhonpathom, Thailand \\ "Corresponding author: Dr Karl Peltzer, HIV/AIDS/STIs and TB (HAST) Research Programme, Human Sciences Research Council, Pretorius St 134, Pretoria, South Africa. E-mail: \\ kpeltzer@hsrc.ac.za
}

Received 2016 September 10; Revised 2017 July 22; Accepted 2017 September 02.

\begin{abstract}
Objectives: The purpose of the study was to investigate the prevalence and associated factors of being in a physical fight in "association of Southeast Asian nations" (ASEAN) member states.

Methods: The total sample consisted of 30284 adolescents aged 13 - 15 years from seven ASEAN countries that were included in the cross-sectional "global school-based student health survey" (GSHS) between 2007 and 2013.

Results: The prevalence of "being in a physical fight in the past 12 months" across seven ASEAN countries (excluding Brunei) was 30.1\%, ranging from below 15\% in Cambodia and Myanmar to more than 30\% in Indonesia, Malaysia, Philippines and Thailand. In multivariate logistic regression analysis, sociodemographic factors (younger age, being male, the experience of hunger) and risk behavior (sedentary behavior, ever had sex, tobacco use, alcohol use, truancy, being bullied, and having sustained an injury) were found to be associated with "having been in a physical fight" in the past year. Lack of protective social-familial factors (low peer support and low parental or guardian support) were only associated with physical fighting in bivariate analyses.

Conclusions: A significant proportion of physical fighting was found in ASEAN calling for interventions aimed to prevent physical fighting considering identified associated factors.
\end{abstract}

Keywords: Physical Substance Substance Use, Violence, Injury, Psychological Distress, Protective Factors, School Adolescents, ASEAN

\section{Background}

Youth violence (bullying, slapping, hitting or assault) is a significant public health problem and may start early and continue into adulthood (1). Experiencing violence during childhood may contribute to health risk behaviors, psycho-social problems and academic problems $(2,3)$. Globally, one in three adolescents had been "in a physical fight in the past 12 months" (4) and $10.7 \%$ of male in $2.7 \%$ of female school adolescents were involved in frequent (4 or more times) physical fighting in the past 12 months (2). Across 28 countries, the highest mean prevalence of any "physical fighting in the past 12 months" was found among adolescents in the Eastern Mediterranean region (46.7\%), and the lowest in the USA (31.4\%) (5). In the Asian region, $27.4 \%$ of school children reported "having been in a physical fight in the past 12 months" in Malaysia (6) and in the Philippines 50.0\% (7). There is a lack of contextual data on youth violence (physical fighting) in the "association of Southeast Asian nations" (ASEAN) member states.

Factors associated with physical fighting in adoles- cents can be grouped into sociodemographic factors, risk behaviors, including psychological distress, and lack of protective social-familial factors (8). Sociodemographic factors may include, male gender $(3,9,10)$, decreased with age $(3,11)$, low economic status $(3,12)$, living in lower income countries (2). Risk behaviors may include alcohol use $(6,9,13,14)$, smoking $(6,9,10,14-16)$, bullying victimization $(3,6,10,15,17,18)$, being sexually active (16), sedentary behavior $(14,17)$, and psychological distress $(12,15-17)$. Lack of social-familial protective factors may include lack of peer support (13), and lack of parental support $(9,10,12,13,19)$.

The purpose of the study was to investigate the prevalence and associated factors of being in a physical fight in "association of Southeast Asian nations" (ASEAN) member states.

\section{Methods}

\subsection{Sample and Procedure}

This investigation utilized existing and publicly available data from the "global school-based student health sur- 
vey" (GSHS) from seven ASEAN countries (20). A "two-stage cluster sample design" with selecting schools and then classes were used to gather data representative of all students in grades 6 to 10 in each country" (20). The participating students were asked to complete a questionnaire under the direction of trained research assistants (20).

\subsection{Measures}

The study instruments used in this study were from the GSHS (20) (see Table 1). "Sedentary behavior was defined as spending 3 or more hours per day sitting when not in school or doing homework." (21). "Physical inactivity was defined as obtaining less than 60 minutes of moderate to vigorous-intensity physical activity per day on at least 5 days per week." (21).

Based on self-reported body weight and height, the "international age- and gender-specific child body mass index (BMI)" was used to classify children as overweight and obese (22). Psychological distress was assessed with three items (no close friends, feeling often or always lonely, and suicidal ideation), and parental or guardian support was also measured with three items (often or always supervision, connectedness and bonding) (see Table 1).

\subsection{Data Analysis}

Using STATA software version 13.0 "(Stata Corporation, College Station, Texas, USA)" data were analysed taking into account for the sampling design. In the analysis each country sample was restricted to the 13 to 15 years age range, so as to compare study samples across countries. Associations between socio-demographics, risk behavior, socialfamilial protective factors and past 12 months physical fighting among school adolescents were analyzed calculating odds ratios (OR). Logistic regression estimated the impact of independent variables on having experienced physical fighting in the past 12 months (dependent variable), with the inclusion of significant bivariate analysis variables in the final multivariate model. The proportions, $P$ value and the reported $95 \%$ confidence intervals were adjusted for the multistage stratified cluster study design.

\section{Results}

\subsection{Sample Characteristics}

The overall sample included 30284 school-going children (aged 13 - 15 years) from seven ASEAN member states. The sample size in the participating individual countries ranged from as low as 1734 in Cambodia to as high as 16066 in Malaysia, 48.5 were male students and $51.5 \%$ were female students, and the overall mean age was 14.0 years $(S D=0.8)$. The year of data collection ranged from 2007 in Indonesia and Myanmar to 2013 in Cambodia and Vietnam, and the overall response rate ranged from $82 \%$ in the Philippines to $96 \%$ in Vietnam. Overall, $30.1 \%$ of the students reported "being in a physical fight in the past year", 40.0\% among boys and $20.7 \%$ among girls. There were country variations in the prevalence of physical fighting, ranging from below 15\% in Cambodia and Myanmar to more than 30\% in Indonesia, Malaysia, Philippines and Thailand. Among boys, the prevalence of being in a physical fight was higher in students residing in an upper middle income country (Malaysia, Thailand) than in a low or lower middle country (Cambodia, Indonesia, Myanmar, Philippines and Vietnam) (23) (see Table 2).

\subsection{Associations with Being in a Physical Fight}

In multivariate logistic regression analysis, sociodemographic factors (younger age), being male, the experience of hunger) and risk behavior (leisure time sitting of 3 or more hours a day, ever had sex, current tobacco use, current alcohol use, truancy in the past month, being bullied in the past month, and "having sustained an injury in the past year") were found to be associated with "having been in a physical fight in the past year". Lack of protective social-familial factors (low peer support and low parental or guardian support) were only associated with physical fighting in bivariate analyses (see Table 3 ).

\section{Discussion}

The study investigated in a large sample of schoolgoing adolescents across seven ASEAN countries the prevalence and correlates of physical fighting. The prevalence of past 12 months physical fighting in this study was lower than in previous studies (5) in different world regions, except for USA, which had a similar prevalence. However, the study found a considerable country differences in the prevalence of physical fighting experiences, ranging from below 15\% in Cambodia and Myanmar to more than 30\% in Indonesia, Malaysia, Philippines and Thailand. Some previous studies seem to confirm a problem of different forms of youth violence in Indonesia (25), Malaysia (15), Philippines $(7,26)$ and Thailand (27-29). It is, however, not clear why such large country differences were found, some authors (e.g., 5), propose that "cultural norms and practices" may affect the proportion of physical fighting among young people. The proportion of physical fighting among adolescents in the ASEAN region, in particular in Indonesia, Malaysia, Philippines and Thailand, is a concern and calls for intervention programmes.

In agreement with previous studies (3, 9-12), this study found a higher prevalence of physical fighting among boys 


\begin{tabular}{|c|c|c|}
\hline Variables & Question & Response Options \\
\hline In physical fight & "During the past 12 months, how many times were you in a physical fight?" & $1=0$ times to $8=12$ or more times \\
\hline Hunger & $\begin{array}{l}\text { "During the past } 30 \text { days, how often did you go hungry because there was not enough food in your } \\
\text { home?" }\end{array}$ & $1=$ never to $5=$ always \\
\hline Leisure time sedentary behavior & $\begin{array}{l}\text { "How much time do you spend during a typical or usual day sitting and watching television, playing } \\
\text { computer games, talking with friends, or playing cards?" }\end{array}$ & $1=$ Less than 1 hour per day $\ldots 3=3$ to 4 hours per day $\ldots 6=8$ or more hours a day \\
\hline Leisure time physical activity & $\begin{array}{l}\text { "During the past } 7 \text { days, on how many days were you physically active for a total of at least } 60 \text { minutes } \\
\text { per day?" }\end{array}$ & $0=0$ days to $8=7$ days \\
\hline Height & "How tall are you without your shoes on?" & \\
\hline Weight & "How much do you weigh without your shoes on?" & \\
\hline Ever sex & "Have you ever had sexual intercourse?" & $1=\mathrm{yes}, 2=$ no \\
\hline Current smoking cigarettes & "During the past 30 days, on how many days did you smoke cigarettes?" & $1=0$ days to $7=$ All 30 days \\
\hline Current other tobacco use & $\begin{array}{l}\text { "During the past } 30 \text { days, on how many days did you use any other form of tobacco, such as chewing } \\
\text { tobacco leaves?" }\end{array}$ & $1=0$ days to $7=$ all 30 days \\
\hline Current alcohol use & "During the past 30 days, on how many days did you have at least one drink containing alcohol?" & $1=0$ days to $7=$ All 30 days \\
\hline School truancy & "During the past 30 days, on how many days did you miss classes or school without permission?" & $1=0$ days to $5=10$ or more days \\
\hline Bullied & "During the past 30 days, on how many days were you bullied?" & $1=0$ day to $7=$ all 30 days \\
\hline Injury & "During the past 12 months, how many times were you seriously injured?" & $1=0$ times to $8=12$ or more times \\
\hline \multicolumn{3}{|l|}{ Psychological distress } \\
\hline Close friends & “How many close friends do you have?" & $1=0$ to $4=3$ or more \\
\hline Lonely & "During the past 12 months, how often have you felt lonely?" & $1=$ never to $5=$ always \\
\hline \multirow[t]{2}{*}{ Suicidal ideation } & "During the past 12 months, did you ever seriously consider attempting suicide?" & $1=$ yes, $2=$ no \\
\hline & Social-familial factors & \\
\hline Peer support & "During the past 30 days, how often were most of the students in your school kind and helpful?" & $1=$ never to $5=$ always \\
\hline Parental or guardian supervision & $\begin{array}{l}\text { "During the past } 30 \text { days, how often did your parents or guardians check to see if your homework was } \\
\text { done?" }\end{array}$ & $1=$ never to $5=$ always \\
\hline Parental or guardian connectedness & $\begin{array}{l}\text { "During the past } 30 \text { days, how often did your parents or guardians understand your problems and } \\
\text { worries?" }\end{array}$ & $1=$ never to $5=$ always \\
\hline Parental or guardian bonding & $\begin{array}{l}\text { "During the past } 30 \text { days, how often did your parents or guardians really know what you were doing } \\
\text { with your free time?" }\end{array}$ & $1=$ never to $5=$ always \\
\hline
\end{tabular}

than girls, younger than older students and school children with a poorer (experiencing hunger as a proxy of socioeconomic status) than richer family background. The finding that physical fighting was more frequent among boys than girls in all countries except for Cambodia was not unexpected, traditional masculine gender socialization may contribute to this $(6,9)$. The declines of physical fighting with age "may be due to young people developing the cognitive, emotional, behavioral and verbal resources to cope with frustrations and conflicts in a more constructive and less physical manner as they grow older." (30). Lower economic status may result in social conditions promoting acceptance in society (3) and biological effects of hunger may increase emotional stress and violence (3). Contrary to a previous review in school children from 79 countries (2) that found a higher prevalence of physical fighting in students living in lower income countries, this study found, among boys that physical fighting was higher in the upper middle income compared to lower income countries. It is possible that in upper middle income countries income inequality was higher than in low or lower middle income countries, contributing, thus, to higher rates of physical fighting among boys.
In previous studies $(6,9,10,12-18)$, various risk behaviors were found to be associated with being in a physical fight, which were also found in this study, including alcohol use, smoking, bullying victimization, truancy, being sexually active and sedentary behavior. In bivariate analysis, psychological distress was also found to increase the odds for physical fighting, as found in previous studies (12, 15-17). Various researchers (6, 8-10) indicated that we may have here a clustering of unhealthy behaviors, which could mean that interventions should also address multiple risk behaviors in adolescents.

Regarding social-familial protective factors, this study found in bivariate analysis that lack of peer and parental support was correlated with physical fighting, which was found in several studies conducted previously $(9,10,12,13$, 19). This finding could possibly mean that the promotion of a social-familial supportive atmosphere could aid in the reduction of physical fighting in school children.

Study limitations include the cross-sectional study design and that the study includes only school going adolescents. The prevalence of physical fighting may differ between school-going and non-school going adolescents. Moreover, data were collected by self-report, which may 
Table 2. Sample Characteristics by Gender

\begin{tabular}{|c|c|c|c|c|}
\hline \multirow{3}{*}{$\begin{array}{l}\text { Variable } \\
\text { Socio-demographics }\end{array}$} & \multirow{3}{*}{$\begin{array}{l}\text { Sample } \\
\text { No.(\%) }\end{array}$} & \multicolumn{3}{|c|}{ Prevalence of Having Been in a Physical Fight } \\
\hline & & All & Male & Female \\
\hline & & $\%(95 \% \mathrm{CI})$ & $\%(95 \% \mathrm{CI})$ & $\%(95 \% \mathrm{CI})$ \\
\hline \multicolumn{5}{|l|}{ Country } \\
\hline All & 30284 & $30.1(28.4-31.8)$ & $40.0(38.0-42.1)$ & $20.7(19.1-22.5)$ \\
\hline Brunei Darussalam (24) & & $24.4(21.5-27.5)$ & $31.9(27.4-36.8)$ & $17.1(14.0-20.8)$ \\
\hline Cambodia & $1734(5.7)$ & $13.8(11.7-16.1)$ & $15.3(12.2-19.0)$ & $12.2(9.5-15.4)$ \\
\hline Indonesia & $2867(9.5)$ & $33.7(30.4-37.1)$ & $47.6(43.4-51.7)$ & $20.1(17.0-23.6)$ \\
\hline Malaysia & $16095(53.1)$ & $30.1(28.5-31.7)$ & $38.5(36.7-40.3)$ & $21.9(20.1-23.8)$ \\
\hline Myanmar & $1983(6.5)$ & $14.6(10.9-19.3)$ & $21.0(16.6-26.2)$ & $8.1(5.2-12.5)$ \\
\hline Philippines & $3640(12.0)$ & $37.7(33.9-41.8)$ & $44.2(39.4-49.0)$ & $31.8(27.8-36.1)$ \\
\hline Thailand & $2223(7.3)$ & $34.1(29.9-38.6)$ & $47.2(42.8-51.2)$ & $21.4(18.0-25.4)$ \\
\hline Vietnam & $1742(5.8)$ & $21.8(18.5-26.5)$ & $33.4(29.0-38.1)$ & $11.8(9.0-15.2)$ \\
\hline \multicolumn{5}{|l|}{ Age in years } \\
\hline 13 & $9130(25.8)$ & $34.4(31.5-37.3)$ & $44.5(40.6-48.3)$ & $24.8(21.9-28.1)$ \\
\hline 14 & $10972(39.2)$ & $29.6(27.7-31.6)$ & $40.4(37.6-43.1)$ & $19.5(17.5-21.7)$ \\
\hline 15 & $10182(34.9)$ & $27.5(25.2-29.9)$ & $36.4(33.4-39.5)$ & $19.0(16.9-21.3)$ \\
\hline \multicolumn{5}{|l|}{ Hunger } \\
\hline Never & $12658(43.1)$ & $22.9(21.0-24.9)$ & $32.9(30.2-35.8)$ & $14.4(12.6-16.5)$ \\
\hline Rarely & $7876(25.3)$ & $33.4(31.3-35.6)$ & $43.3(40.8-45.9)$ & $23.8(21.2-26.6)$ \\
\hline Sometimes/mostly/always & $9663(31.6)$ & $37.3(35.2-39.5)$ & $46.3(43.5-49.1)$ & $27.8(25.6-30.2)$ \\
\hline \multicolumn{5}{|l|}{ Country income } \\
\hline Upper middle income & $18318(60.5)$ & $32.5(29.9-35.2)$ & $43.7(40.9-46.6)$ & $21.6(19.4-24.1)$ \\
\hline Low/lower middle income & $11966(39.5)$ & $29.4(27.4-31.4)$ & $38.9(36.5-41.4)$ & $20.5(18.4-22.7)$ \\
\hline \multicolumn{5}{|l|}{ Risk behavior } \\
\hline Sitting 3 or more hours & $10896(33.0)$ & $33.7(31.7-35.7)$ & $44.9(42.0-47.8)$ & $23.8(21.6-26.1)$ \\
\hline Physically inactive & $23590(80.4)$ & $30.0(28.3-31.7)$ & $40.1(38.0-42.2)$ & $21.3919 .6-23.2)$ \\
\hline Overweight or obese & $4823(9.9)$ & $33.8(30.3-37.5)$ & $43.4(38.3-47.9)$ & $22.4(18.8-26.4)$ \\
\hline Ever sex & $1509(4.1)$ & $43.1(38.2-48.2)$ & $52.5(46.7-58.2)$ & $31.9(24.6-40.2)$ \\
\hline Current tobacco use & $2661(8.8)$ & $59.3(55.9-62.6)$ & $60.5(56.8-64.1)$ & $54.8(46.7-65.6)$ \\
\hline Current alcohol use & $2337(11.9)$ & $49.7(45.9-53.6)$ & $57.0(52.2-61.6)$ & $37.6(33.0-42.5)$ \\
\hline Truancy & $7255(24.8)$ & $45.8(43.1-48.5)$ & $54.0(51.2 \cdot 56.7)$ & $34.9(31.5-38.4)$ \\
\hline Bullied & $7648(35.6)$ & $45.5(43.1-47.8)$ & $54.9(52.2-57.6)$ & $35.9(32.8-39.0)$ \\
\hline Sustained injury & $9347(39.6)$ & $46.6(44.4-48.8)$ & $55.3(52.7-57.9)$ & $35.2(32.1-38.3)$ \\
\hline \multicolumn{5}{|l|}{ Psychological distress } \\
\hline 0 & $24959(80.8)$ & $27.4(25.8-29.0)$ & $37.0(34.9-39.1)$ & $17.9(16.4-19.5)$ \\
\hline 1 & $3883(15.7)$ & $38.6(35.5-41.8)$ & $51.0(47.4-54.6)$ & $29.4(25.4-33.7)$ \\
\hline $2-3$ & $764(3.4)$ & $45.6(39.8-51.6)$ & $57.1(47.9-65.8)$ & $38.1(31.6-45.0)$ \\
\hline \multicolumn{5}{|l|}{ Social - familial protective factors } \\
\hline Peer support(mostly/always) & $12024(40.4)$ & $24.0(22.2-25.9)$ & $34.3(31.4-37.3)$ & $16.2(14.4-18.1)$ \\
\hline \multicolumn{5}{|l|}{ Parental/guardian support } \\
\hline \multicolumn{5}{|l|}{ index } \\
\hline 0 & $11177(39.9)$ & $35.6(33.3-37.9)$ & $45.2(42.3-48.2)$ & $25.8(23.5-28.2)$ \\
\hline 1 & $7929(26.8)$ & $31.6(29.3-34.0)$ & $40.9(37.9-44.0)$ & $22.7(20.1-25.6)$ \\
\hline $2 \cdot 3$ & $9034(33.3)$ & $23.2(21.5-25.0)$ & $34.0(31.5-36.5)$ & $14.4(12.6-16.4)$ \\
\hline
\end{tabular}

Abbreviation: $\mathrm{Cl}$,Confidence Interval.

have biased the results.

\subsection{Conclusion}

The study found in a large sample of adolescents across seven ASEAN member states a significant proportion of physical fighting behavior. Several sociodemographic and 
Table 3. Associations Between Socio-Demographics, Risk Behavior, and Physical Fighting Prevalence among Social-Familial Protective Factor Variables in School Going Adolescents from 7 ASEAN Countries

\begin{tabular}{|c|c|c|}
\hline Variable & $\operatorname{UOR}(95 \% \mathrm{CI})$ & $\operatorname{AOR}(95 \% \mathrm{CI})$ \\
\hline \multicolumn{3}{|l|}{ Socio-demographics } \\
\hline \multicolumn{3}{|l|}{ Age in years } \\
\hline 13 & 1 (Reference) & 1 (Reference) \\
\hline 14 & $0.80(0.70-0.92)^{\mathrm{a}}$ & $0.75(0.62-0.90)^{\mathrm{a}}$ \\
\hline 15 & $0.72(0.62-0.84)^{b}$ & $0.62(0.49-0.78)^{b}$ \\
\hline \multicolumn{3}{|l|}{ Sex } \\
\hline Female & 1 (Reference) & 1(Reference) \\
\hline Male & $2.55(2.30-2.83)^{\mathrm{b}}$ & $2.59(2.13-3.15)^{b}$ \\
\hline \multicolumn{3}{|l|}{ Hunger } \\
\hline Never & 1 (Reference) & 1 (Reference) \\
\hline Rarely & $1.69(1.48-1.92)^{\mathrm{b}}$ & $1.29(1.05-1.58)^{\mathrm{C}}$ \\
\hline Sometimes/mostly/always & $2.00(1.79-2.24)^{b}$ & $1.37(1.15-1.62)^{b}$ \\
\hline \multicolumn{3}{|l|}{ Country income } \\
\hline Upper middle income & 1(Reference) & - \\
\hline Low/lower middle income & $0.86(0.74-1.01)$ & \\
\hline \multicolumn{3}{|l|}{ Risk behavior } \\
\hline Sitting 3 or more hours $($ base $=<3$ ) & $1.29(1.19-1.41)^{\mathrm{b}}$ & $1.35(1.16-1.57)^{b}$ \\
\hline Physically inactive (base = active) & $1.00(0.89-1.13)$ & - \\
\hline Overweight or obese $($ base $=$ no $)$ & $1.25(1.08-1.44)^{\mathrm{a}}$ & $1.09(0.90-1.33)$ \\
\hline Ever sex $($ base $=$ no $)$ & $2.06(1.64-2.58)^{b}$ & $1.72(1.18-2.50)^{\mathrm{a}}$ \\
\hline Current tobacco use (base $=$ no) & $4.01(3.50-4.58)^{b}$ & $1.771 .33 \cdot 2.37^{\mathrm{b}}$ \\
\hline Current alcohol use (base = no) & $2.73(2.30-3.25)^{\mathrm{b}}$ & $2.07(1.56-2.74)^{\mathrm{b}}$ \\
\hline Truancy $($ base $=$ no $)$ & $2.47(2.19-2.80)^{\mathrm{b}}$ & $1.56(1.25-1.93)^{\mathrm{b}}$ \\
\hline Bullied $($ base $=$ no $)$ & $3.27(2.95-3.64)^{\mathrm{b}}$ & $2.50(2.13-2.93)^{b}$ \\
\hline Sustained injury $($ base $=$ no $)$ & $3.87(3.43-4.36)^{\mathrm{b}}$ & $2.21(1.90-2.58)^{b}$ \\
\hline \multicolumn{3}{|l|}{ Psychological distress } \\
\hline 0 & 1 (Reference) & 1 (Reference) \\
\hline 1 & $1.67(1.47-1.89)^{b}$ & $1.14(0.92-1.41)$ \\
\hline $2-3$ & $2.23(1.81-2.75)^{\mathrm{b}}$ & $1.25(0.72-2.18)$ \\
\hline \multicolumn{3}{|l|}{ Social - familial protective factors } \\
\hline Peer support (mostly/always) & $0.59(0.53-0.65)^{b}$ & $0.95(0.80-1.12)$ \\
\hline \multicolumn{3}{|l|}{ Parental/guardian support index } \\
\hline 0 & 1 (Reference) & 1(Reference) \\
\hline 1 & $0.84(0.75-0.93)^{b}$ & $0.93(0.77-1.12)$ \\
\hline $2 \cdot 3$ & $0.55(0.49-0.61)^{\mathrm{b}}$ & $0.86(0.72-1.02)$ \\
\hline
\end{tabular}

a number of clustering risk factors were identified, which can help guide interventions to prevent physical fighting in this population.

\section{Acknowledgments}

"We thank the world health organization and the centers for disease control and prevention for making the data for this analysis publicly available." “We are also grateful to the country coordinators from Cambodia (Chher Tepirou), Indonesia (Rachmalina S. Prasodjo), Malaysia (Noor Ani Ahmad), Myanmar (Aung Tun), Philippines (Agnes BenegasSegarra), Thailand (Pensri Kramomtong), Vietnam (LE Thi Hoan), for collecting the GSHS data." "The Ministries of Education and Health and the study participants in the GSHS in the six ASEAN countries are acknowledged. The governments of the respective study countries and the world health organization did not influence the analysis nor did they have an influence on the decision to publish these findings."

\section{References}

1. World Health Organization (WHO) . Global status report on violence prevention 2014 [cited 2 April]. Available from: file:///C:/Users/user\% 201/Downloads/9789241564793_eng.pdf.

2. Elgar FJ, McKinnon B, Walsh SD, Freeman J, D. Donnelly P, de Matos MG, et al. Structural Determinants of Youth Bullying and Fighting in 79 Countries. J Adolesc Health. 2015;57(6):643-50. doi: 10.1016/j.jadohealth.2015.08.007. [PubMed: 26476856].

3. Pickett W, Molcho M, Elgar FJ, Brooks F, de Looze M, Rathmann K, et al. Trends and socioeconomic correlates of adolescent physical fighting in 30 countries. Pediatrics. 2013;131(1):e18-26. doi: 10.1542/peds.20121614. [PubMed: 23209107].

4. United Nations Children's Fund (UNICEF) . Hidden in Plain Sight: A statistical analysis of violence against children 2014. [cited 2 April]. Available from: http://reliefweb.int/sites/reliefweb.int/files/ resources/Hidden_in_plain_sight_statistical_analysis_EN_3_ Sept_2014.pdf.

5. Swahn MH, Gressard L, Palmier JB, Yao H, Haberlen M. The prevalence of very frequent physical fighting among boys and girls in 27 countries and cities: regional and gender differences.J Environ Public Health. 2013;2013:215126. doi: 10.1155/2013/215126. [PubMed: 23935643].

6. Mat Hussin SF, Abd Aziz NS, Hasim H, Sahril N. Prevalence and factors associated with physical fighting among Malaysian adolescents. Asia Pac J Public Health. 2014;26(5 Suppl):108S-15S. doi: 10.1177/1010539514542423. [PubMed: 25038192].

7. Rudatsikira E, Mataya RH, Siziya S, Muula AS. Association between bullying victimization and physical fighting among Filipino adolescents: results from the Global School-Based Health Survey. Indian J Pediatr. 2008;75(12):1243-7. doi: 10.1007/s12098-008-0244-x. [PubMed: 19190879].

8. Peltzer K, Pengpid S. Physical fighting and social correlates among inschool adolescents in the caribbean. Mediterr J Soc Sci. 2014;5(14):531-8. doi: 10.5901/mjss.2014.v5n14p531.

9. Rudatsikira E, Siziya S, Kazembe LN, Muula AS. Prevalence and associated factors of physical fighting among school-going adolescents in Namibia. Ann Gen Psychiatry. 2007;6:18. doi: 10.1186/1744-859X-6-18. [PubMed: 17650328].

10. Rudatsikira E, Muula AS, Siziya S. Prevalence and correlates of physical fighting among school-going adolescents in Santiago, Chile. Rev Bras Psiquiatr. 2008;30(3):197-202. doi: 10.1590/S151644462008000300004. [PubMed: 18833418].

11. Grufman M, Berg-Kelly K. Physical fighting and associated health behaviours among Swedish adolescents. Acta Paediatr. 1997;86(1):77-81. doi: 10.1111/j.1651-2227.1997.tb08836.x. [PubMed: 9116431].

12. Shetgiri R, Kataoka S, Ponce N, Flores G, Chung PJ. Adolescent fighting: racial/ethnic disparities and the importance of families and schools. Acad Pediatr. 2010;10(5):323-9. doi: 10.1016/j.acap.2010.06.004. [PubMed: 20674530]. 
13. Fraga S, Ramos E, Dias S, Barros H. Physical fighting among schoolgoing Portuguese adolescents: social and behavioural correlates. Prev Med. 2011;52(5):401-4. doi: 10.1016/j.ypmed.2011.02.015. [PubMed: 21371501].

14. Rudatsikira E, Muula AS, Siziya S. Variables associated with physical fighting among US high-school students. Clin Pract Epidemiol Ment Health. 2008;4:16. doi:10.1186/1745-0179-4-16. [PubMed: 18510746].

15. Lee LK, Chen PC, Lee KK, Kaur J. Violence-related behaviours among Malaysian adolescents: a cross sectional survey among secondary school students in Negeri Sembilan. Ann Acad Med Singapore. 2007;36(3):169-74. [PubMed: 17450261].

16. Alikasifoglu M, Erginoz E, Ercan O, Uysal O, Kaymak DA, Iiter O. Violent behaviour among Turkish high school students and correlates of physical fighting. EurJ Public Health. 2004;14(2):173-7. doi:10.1093/eurpub/14.2.173. [PubMed: 15230504].

17. Celedonia KL, Wilson ML, El Gammal HA, Hagras AM. Physical fighting among Egyptian adolescents: social and demographic correlates among a nationally representative sample. PeerJ. 2013;1:e125. doi: 10.7717/peerj.125. [PubMed: 24024080].

18. Muula AS, Herring P, Siziya S, Rudatsikira E. Bullying victimization and physical fighting among Venezuelan adolescents in Barinas: results from the Global School-Based Health Survey 2003. Ital J Pediatr. 2009;35(1):38. doi: 10.1186/1824-7288-35-38. [PubMed: 19939261].

19. Williams K, Rivera L, Neighbours R, Reznik V. Youth violence prevention comes of age: research, training and future directions. Annu Rev Public Health. 2007;28:195-211. doi: 10.1146/annurev.publhealth.28.021406.144111. [PubMed: 17367286].

20. Centers for Disease Control (CDC). The Global School and Health Survey background 2015. [cited 18 December]. Available from: http: //www.cdc.gov/gshs/background/index.

21. Guthold R, Cowan MJ, Autenrieth CS, Kann L, Riley LM. Physical activity and sedentary behavior among schoolchildren: a 34-country com-
parison.J Pediatr. 2010;157(1):43-49 e1. doi: 10.1016/j.jpeds.2010.01.019. [PubMed: 20304415].

22. Cole TJ, Bellizzi MC, Flegal KM, Dietz WH. Establishing a standard definition for child overweight and obesity worldwide: international survey. BMJ. 2000;320(7244):1240-3. [PubMed: 10797032].

23. The World Bank. Countries and economies 2015. [cited 28 Dec]. Available from: http://data.worldbank.org/country/.

24. Centers for Disease Control (CDC) . Global School-based Student Health Survey. Brunei Darussalam 2014 Fact Sheet 2015. [cited 10 Dec] Available from: http://www.who.int/chp/gshs/Brunei_Darussalam_ 2014_FactSheet.pdf.

25. Kristiansen S. Violent youth groups in Indonesia: the cases of Yogyakarta and Nusa Tenggara Barat. Sojourn. 2003;18(1):110-38. [PubMed: 21853624].

26. Peltzer K, Pengpid S. Health Risk Behaviour among In-School Adolescents in the Philippines: Trends between 2003, 2007 and 2011, A Cross-Sectional Study. Int J Environ Res Public Health. 2015;13(1):73. doi: 10.3390/ijerph13010073. [PubMed: 26712770].

27. Saiphoklang OA, Wongboonsin K, Wongboonsin P, Perngparn U, Cottler LB. The Association Between Weapon Carrying and Health Risk Behaviors Among Adolescent Students in Bangkok, Thailand. J Interpers Violence. 2015 doi: 10.1177/0886260515596977. [PubMed: 26228918].

28. Sirirassamee T, Sirirassamee B. Health risk behavior among Thai youth: national survey 2013. Asia Pac J Public Health. 2015;27(1):76-84. doi: 10.1177/1010539514548759. [PubMed: 25183211].

29. Pengpid S, Peltzer K. Bullying and its associated factors among school-aged adolescents in Thailand. ScientificWorldJournal. 2013;2013:254083. doi: 10.1155/2013/254083. [PubMed: 23476124].

30. World Health Organization (WHO) . Europe. Bullying and physical fights among adolescents 2016. [cited 2 April]. Available from: http://www.euro.who.int/_data/assets/pdf_file/0005/303485/ HBSC-No.7_factsheet_Bullying.pdf. 